\title{
IMPLEMENTATION OF THE NEW SUB-PROGRAM FOR MATHEMATICS TEACHERS AT THE UNIVERSITY OF LATVIA
}

\author{
Maruta Avotinga, Elīna Buliṇa, Guna Brenda Pogule \\ University of Latvia, Latvia
}

\begin{abstract}
A qualified and knowledgeable teacher is a foundation of a good education, responsible for motivating a pupil to acquire new knowledge and apply it in different ways. By 2020, in Latvia, a teacher's qualification could be obtained in various higher education institutions, which had dozens of study programs in different faculties, so it was difficult for school graduates to orientate in a large number of programs and requirements. Between 2018 and 2020, within the European Social Fund project "Education and Pedagogy" of the University of Latvia, a joint professional bachelor's study program "Teacher" for several universities was developed. This program has several sub-programs - one of which is the sub-program "Mathematics Teacher" where in September 2020, the first students started their studies. In the new program significant changes were made compared to the previous programs. In this article we analyze the changes made to the study courses while comparing them with a professional bachelor's program "Secondary School Mathematics Teacher" in the Faculty of Chemistry at the University of Latvia.

The COVID-19 pandemic brought changes to the planned study process, which also affected the implementation of the new program. Thus, in September and early October 2020 students at the University of Latvia attended lectures in person, but in mid-October the remote study process began. Since studying and lecturing online is a new experience not only for students, but also for the majority of lecturers and professors, it was a great challenge to reorganize the study process from studying in person to remote learning without losing quality and feedback acquisition. Given the fact that pupils and students in Latvia studied remotely also in Spring 2020, several surveys were conducted, focusing on remote learning process in schools. In order to see how remote studies affect students of science, technology, engineering and mathematics (STEM) programs, a survey about difficulties of remote learning process for $1^{\text {st }}$ year students in the sub-program "Mathematics Teacher" was conducted.
\end{abstract}

Keywords: mathematics teacher education, mathematics study courses, professional bachelor program Teacher, remote learning, teacher education. 


\section{Introduction}

The Organization for Economic Cooperation and Development (OECD) International Training Environment Study TALIS 2018 (OECD TALIS, 2019) provides information that the average age of teachers in Latvia is 48 years, which is higher than average age of teachers in OECD countries and TALIS Member States (i. e., 44 years). In addition, 51\% of teachers in Latvia are aged 50 and over (the OECD average is 34\%). This means that in next decade Latvia will need to replace about every second teacher from now available teachers. Thereby consideration should be given to the importance of a new teacher preparation accordingly to new tendencies in education and teaching of subjects, including both theoretical knowledge and practical skills in working with pupils.

The very basis of a good education is a qualified and knowledgeable teacher. Therefore, it is important that teachers are prepared for all challenges they might face during their carrier in today's schools. By 2020, everyone interested in being a teacher could choose to obtain their teacher's qualification in one of many various higher education institutions in Latvia, which had dozens of study programs in different faculties that made it difficult for school graduates to understand and orientate in various programs and their requirements. Between 2018 and 2020 within the European Social Fund project “The University of Latvia's Innovative, Research-Based field of studies "Education and Pedagogy" study program" a joint professional bachelor's study program "Teacher" (University of Latvia, 2020) was expounded. It was developed under the management of experienced professionals at the University of Latvia, in cooperation with leading teacher education institutions in Latvia - Daugavpils University, Liepaja University and Rezekne Academy of Technologies.

The goal of a study program is to provide professional bachelor's studies in educational sciences by facilitating the development of the general and professional competence of the teacher in accordance with the profession standard "Teacher" in the study fields selected by the student. Students have a unique opportunity to combine two subjects from the given list (see Table 1), as well as to choose one of the sub-programs:

- Latvian Language and Literature Teacher,

- Mathematics Teacher,

- Russian Language and Literature Teacher,

- Teacher of Social Sciences and History. 
Table 1. Two subject teacher possible combinations

\begin{tabular}{|c|c|}
\hline Basic Subject & Additional Subject \\
\hline English Teacher & English Teacher \\
\hline German Teacher & Biology Teacher \\
\hline Computer Science Teacher & Computer Science Teacher \\
\hline Teacher of Design and Technology & Teacher of Design and Technology \\
\hline \multirow{5}{*}{$\begin{array}{l}\text { Science Teacher (Biology Teacher } \\
\text { or Physics Teacher, or Chemistry } \\
\text { Teacher) }\end{array}$} & Russian as a Foreign Language Teacher \\
\hline & $\begin{array}{l}\text { Latvian as Native and as a Foreign Language } \\
\text { Teacher }\end{array}$ \\
\hline & Mathematics Teacher \\
\hline & German Teacher \\
\hline & $\begin{array}{l}\text { Science Teacher; Physics Teacher; Geography } \\
\text { Teacher; Chemistry Teacher (combination of } \\
\text { any two subjects) }\end{array}$ \\
\hline
\end{tabular}

Changes in teacher training were mostly influenced by changes in the school education, because in Latvian schools during the study year 2020/2021, students of grades 1, 4, 7 and 10 (a gradual transition of other grades to the new curricula will take place in coming years) started to learn following the project "Competency Based Approach in School Curricula" implemented by the National Centre for Education, the aim of which is to develop, approbate, and gradually implement this content of general education and the approach to teaching in school starting from pre-primary to secondary, as a result pupils will gain knowledge, skills and attitudes needed for life nowadays. Thereby it was necessary to introduce changes to teacher training so that they would be ready to work accordingly to the new curricula and would be theoretically prepared, because the changes were not only in a way how pupils should be taught, but also the significant changes were made in the content of Mathematics, especially in the secondary school. The main content changes are returning to teaching elements of Calculus (limits, derivatives, integrals) and Analytical Geometry to secondary school pupils who are learning mathematics at an in-dept level, also importance of probability theory and statistics has been significantly raised (Regulations on State Secondary Education Curricula and Sample Secondary Education Programs, 2019).

Before 2020, Mathematics teacher's qualification could be obtained, for example, at the University of Latvia through the program "Science and Information Technologies Teacher" sub-program "Secondary School Mathematics Teacher" where in 4 years students learned different courses in pedagogy as well as courses in mathematics that have remained without 
changes for many years. In the new program "Teacher" significant changes compared to the program that has been active till 2020 at the University of Latvia have been made. The new program was licensed on August 19, 2020. Main changes will be discussed in the Results and Discussion section. A single and appropriate to modern requirements program attracts potential students. For autumn semester, all 15 state-funded study places were filled, and it is the largest number of the state-funded study places within all sub-programs of the program "Teacher".

Unforeseen difficulties in the implementation of the new program and planned study process were brought by the COVID-19 pandemic. Thereby in September and beginning of October 2020, students at the University of Latvia attended lectures in person, but in middle of October remote learning process began. Since studying and lecturing online is a new experience not only for students, but also for most of the teaching staff, it was a great challenge to organize the qualitative transfer of knowledge and to receive feedback. In a short period of time teaching staff had to reschedule the study process and learn the use of technology while taking into account technical equipment available for their students and themselves (for example, a personal computer, a camera, a graphic display or a tablet, an internet connection, a platform for online lectures). In the Results section summarization of common characteristics and differences about remote study process and studying in person at the University of Latvia will be given.

Not only did schools and universities in Latvia had to quickly switch from studying in person to remote learning due to the COVID-19 pandemic but also many other countries worldwide, see (Azhari \& Fajri, 2021), (Manca \& Delfino, 2021), (Nobre et al., 2021).

\section{Method}

Taking into account that in autumn 2020 in Latvia, pupils and students were studying remotely, several surveys for pupils and teachers were carried out, focusing on remote learning process in schools. To gain the information on how remote learning affected the students at the University of Latvia, a survey about remote learning advantages and disadvantages for $1^{\text {st }}$ year students of the sub-program "Mathematics Teacher" were carried out.

The survey was conducted in January 2021, and it uses the questionnaire method for students of the sub-program "Mathematics Teachers". The questionnaire was created in Google Sheets; potential respondents were reached online via e-mail. In the questionnaire there were open-ended and closeended questions; in total, 19 questions were put forward to the respondents. The results were analyzed quantitatively and qualitatively. Respondents make up 73,3\% of all students of the sub-program "Mathematics Teacher" 
(the questionnaire was filled out by 11 out of 15 students). Since the program had only started in 2020 and does not have many students, the number of respondents was not large, but it is representative.

Questions discussed general information about student's previous education, choice to become a Mathematics teacher, differences between remote study process and studying in person, and courses studied in the $1^{\text {st }}$ semester.

\section{Results and Discussion}

The discussion will be divided in two parts. First part deal with the new professional bachelor's program "Teacher" sub-program "Mathematics Teacher" and the main changes compared to the sub-program "Secondary School Mathematics Teacher" of the program "Science and Information Technologies Teacher". Second part is devoted to the analysis of survey results gained by carrying out the questionnaire for students about studying in person and learning remotely

\section{Main Changes in the Sub-program Mathematics Teacher}

When the new program "Teacher" was developed, a great attention was paid to the structure of the course plan, that is why all the sub-programs have common compulsory courses (see Table 2) whose total amount is 60 ECTS.

Table 2. Compulsory courses for the program "Teacher"

\begin{tabular}{|l|l|}
\hline General education study courses & Theoretical courses in the field \\
\hline $\begin{array}{l}\text { Introduction to Education for Sustainable } \\
\text { Development }\end{array}$ & Inclusive and Special Education \\
\hline Education Management & Information Technology in Education \\
\hline $\begin{array}{l}\text { Legal Aspects of Pedagogical Process in } \\
\text { Education }\end{array}$ & Class Management \\
\hline Psychology for Teachers & Learning and Teaching \\
\hline Research in Education & Socio-emotional Learning in School \\
\hline $\begin{array}{l}\text { Basics of The Professional Activities of } \\
\text { The Teacher }\end{array}$ & \\
\hline State, Civil and Environmental Protection & \\
\hline
\end{tabular}

In order to learn the application of theoretical knowledge in real life, students have five practices in schools with a total of 18 ECTS. The schedule of each practice in school is aligned with the course schedule, that is, students gain theoretical knowledge and straight after it they have practice 
in school to apply the theory in real life situations. At the end of the studies a bachelor thesis (15 ECTS) should be written, and a qualification exam (3 ECTS) should be passed. The total amount of mathematics courses is 120 ECTS; all the mathematics study courses are given in Table 3.

Table 3. Mathematics courses for the sub-program Mathematics teacher

\begin{tabular}{|l|l|}
\hline Algebra for Teachers I, II & Use of Mathematics in Other Fields \\
Analytical Geometry and Its & Methodology of Mathematics I, II, III \\
Methodologies & Calculus and Its Methodology I, II, III \\
Elementary Mathematics Methods & Mathematical Statistics and Its \\
Introduction to Theory of Differential & Methodology \\
Equations & Elements of Mathematical Logics and Set \\
Introduction to Number Theory & Theory \\
Introduction to Probability Theory & Elements of Modern Elementary Algebra \\
Information Technology for The & and Geometry \\
Development of Teaching Materials in & Programming Basics for Teachers \\
Mathematics & School Mathematics Practice I, II, III \\
Information Technology in Mathematics & Basics of Geometry \\
Combinatorics and Elements of Graph & \\
Theory & \\
\hline
\end{tabular}

Compared to the program "Science and Information Technologies Teacher" sub-program "Secondary School Mathematics Teacher" in the sub-program "Mathematics Teacher" in many courses the methodology of the given course also is included, because some of these topics have been included in the school curricula. This is a challenge for the teaching staff, because they need to change the course content and the approach on how lectures should be given and organized - a student has to be encouraged to become an active participant instead of a passive listener. Students of the sub-program "Mathematics Teacher" who graduated from school until 2021 and are going to graduate in a year or two, will have to teach topics they did not learn at school themselves, because many mathematics topics were not included in the previous curricula (Regulations on State Secondary Education Curricula, Subject Standards and Samples of Educational Programs, 2013), so it is important to link theoretical knowledge to the methodology without delay. The study process also focuses on learning and using the Information and Communications Technology (ICT) in Mathematics lessons (the study program "Teacher" has both specific courses and use of the ICT integrated in the study courses), because the ICT is more actively used in schools in the teaching process (Bretscher, 2021), since it helps to ensure the study process and get quick feedback. Nevertheless, in order to include 
new study courses, some courses should be excluded - in mathematics several theoretical courses were reduced, following courses are no longer thought to the future teachers:

- Programming and Computers II,

- Linear Algebra and Analytical Geometry I, II - these courses are divided into two different courses Algebra for Teachers I and Analytical Geometry and its Methodology,

- Introduction to Complex Analysis - some topics of this course are integrated in the course Algebra for Teachers I,

- Differential Equations - the amount of the course is decreased from 6 ECTS to 3 ECTS,

- Methods of Mathematical Physics,

- Physics for Natural Sciences.

Nowadays a serious problem is a huge number of students that decide to leave studies. In Latvia, only $48 \%$ of students graduate in time from the study program they have chosen (OECD, 2019). The largest number of dropout students is at the end of the first semester, because of the difference between school learning process and the study process at the university. Students have to be more self-controlling, and they have to study more independently. To make this transfer smoother, the tradition of teaching Calculus and Analytical Geometry in the $1^{\text {st }}$ semester was changed and in the new program courses "Calculus and its Methodology I" and "Analytical Geometry and its Methodology" are being taught in the $2^{\text {nd }}$ semester, so students who just started their studies would not have a big number of complicated highest mathematics theoretical courses.

\section{Advantages and Disadvantages in the Remote Study Process}

To find out how the $1^{\text {st }}$ semester students of the sub-program Mathematics Teacher rate the remote study process and studying in person, a survey was conducted. In autumn 2020, studies in this sub-program started 15 students, 11 of them participated in the survey.

The main reasons why students decided to choose a teacher's profession were due to their liking for mathematics, good grades in the secondary school mathematics, family tradition, and an encouraging teacher of Mathematics. Nine of respondents are secondary school graduates, but two graduated state gymnasiums. Most of the students applied for this sub-program immediately after graduating the school, but there are also students that graduated school between 2009 and 2013.

Based on admission requirements, to apply to the program "Teacher" the basic subject grade must be 7 or higher. In Figure 1 the information about students' final grade in Mathematics (vertical axis) and their result 
in a final Mathematics exam (horizontal axis) are given. As it can be seen, for students with same grades in the school exam results can differ significantly.

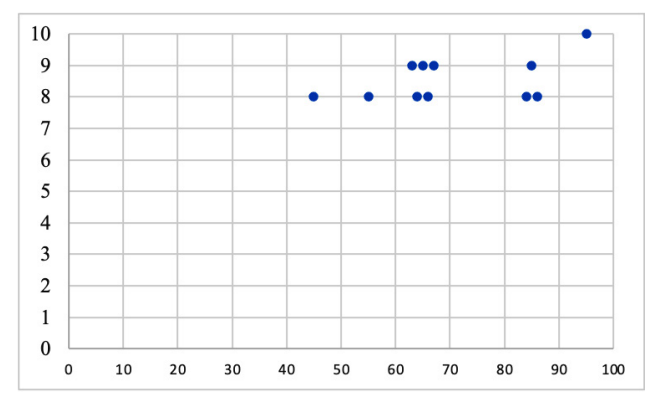

Figure 1. Students' final grade in Mathematics and their result in a final Mathematics exam

In September these students started their studies in person and later continued studies remotely. Thus, giving an opportunity to the students to compare studying in person with studies online through MS Teams platform. Most of these students answered that it is easier to study in person, as main advantages mentioning:

- a direct contact with the lecturer,

- unclear questions can be asked directly when needed,

- you can more easily concentrate on studies,

- communication in person with course mates,

- a lecturer controls whether the students follow the lecture and do the given tasks.

While as advantages of remote studies were given:

- time planning accordingly to everyone's personal needs,

- video recordings where you can repeatedly go through the material,

- you do not have to spend time to get to the faculty,

- you can use lecture materials during your tests.

As an advantage of the remote learning was mentioned that a student can use any materials during their tests and exams, even if it is not allowed by the lecturer who cannot control what students do while sitting at home in front of their computers. All tests must be designed in a way that allows the lecturer to properly assess students' knowledge and to ensure academic honesty during the remote learning process (Paredes et al., 2021).

Usually when students choose full time studies, they expect that all lectures will be held in person. Also, teaching staff, during years of work, has developed methods and approach to teaching in the auditorium in close contact with students. In October 2020 due to the COVID-19 all study process 
had to be held remotely as synchronous online lectures, that significantly differs from the work in the auditorium (Silva et al., 2021). Synchronous and asynchronous distance learning processes have been investigated by (Goksu et al., 2021), where the authors concluded that while using both synchronous and asynchronous distance learning enhances motivation, whereas synchronous learning increases attendance.

Many lecturers had no experience and knowledge of how to give lectures remotely (Dias-Trinidade \& Santo, 2021). It is even more difficult in STEM subjects, where students have to learn fundamental theoretical knowledge, which is hard to do even when studying in person. The main reason why students drop out of the STEM subject programs is a lack of fundamental knowledge that they have not learned or have acquired improperly or insufficiently in the secondary school. In Latvia, the results of the final mathematics exam are the lowest comparing to the results of the final tests in other subjects (National Centre for Education, 2020), average results in Mathematics are about 35\% (in $2018-34.6 \%$, in $2019-32.7 \%$, in $2020-$ $35.4 \%$ ). It should be taken into account that, pupils, when graduating from secondary school, have to pass three mandatory exams - Mathematics, Latvian and a foreign language. Other exams are not mandatory, and pupils choose to pass only those final exams that are needed for applying to the higher education institution they have chosen. Thus, it is hard to judge about the knowledge level of pupils in Latvia in other STEM subjects, such as Physics, Chemistry, Biology. Students in the survey admitted that in the course "Elements of Mathematical Logic and Set Theory" they lacked knowledge about mathematical induction. It can be explained by the fact that in the past 13 years in the final Mathematics exam there has not been a problem about mathematical induction, so many teachers teach this topic superficially or does not teach it at all.

In the survey, most respondents acknowledged that in the $1^{\text {st }}$ semester, the easiest courses were "Psychology for Teachers" and "Principles for the Professional Work of the Teacher" which did not make much difference whether students were studying in person or remotely, since they were actively involved in the training process. From the mathematics course list, considering both the course content and the lecturer's work, students most easily completed the courses "School Mathematics Practice I" and "Algebra for Teachers I" the students appreciated the lecturer's work and teaching methods, as well as given examples from their experience at school. Although in the course "Basics of Programming for Teachers" were a lot of homework and some students had no previous experience in programming, most students appreciated the lectures and the organized consultations that helped them to acquire the course. The most difficult course in the $1^{\text {st }}$ semester was the course "Elements of Mathematical Logic and Set Theory" 
both from the point of view of content and the method of teaching because the lecturer mainly showed only presentations.

Analyzing students' answers and the number of students who passed the session (only 3 students did not pass the session, which is significantly less than in previous years), it can be concluded that the decision to move two higher mathematics courses "Mathematical Analysis and its Methodology I" and "Analytical Geometry and its Methodology" to the $2^{\text {nd }}$ semester has been reasonable, as it has reduced the large gap and students' load in the transition from school to university.

In the survey as major problems in the remote study process were mentioned:

- it is hard to concentrate for studies when you are at home,

- it is more difficult for the lecturers to get feedback and maintain communication with students,

- some lecturers tend to move forward faster through the material,

- difficulty to understand mutual explanations that are not visually represented in the presentation (especially if the graphic display or tablet is not used or it is used inappropriately),

- different technical problems - lack of stable internet connection, inappropriate computer equipment and incompatibility of programs with the computer.

However, as most dangerous disadvantage was mentioned a long time at the computer in one position, that results in mental and physical health problems. Some respondents mentioned that a successful study process depends on the competence of the lecturer, and it is not important whether lectures happen in person or remotely.

\section{Conclusions}

- The professional bachelor's program "Teacher" at the University of Latvia licensed in 2020 corresponds to the new approach to teacher training; its sub-program "Mathematics Teacher" has been approved by the $1^{\text {st }}$ year students who admit that the transition from school to university has been relatively easy. In the future, students should also be interviewed regularly about the study program to keep it appropriate to student needs and the labor market, regarding to the ascending demand for teachers, especially in STEM subjects, in next decade.

- Breaking the tradition of the course acquisition order, in the sub-program "Mathematics teachers" some mathematics study courses were moved to next semester to reduce the large gap between the school and the university learning process and students' load in the $1^{\text {st }}$ semester. One more crucial change is methodology integration in some courses 
content, which allows future teachers to discuss methodological aspects and current issues in the school curricula. According to the survey these changes are appreciated by the students.

- The lecturer has a big role in the acquisition of the study course, regardless of teaching in person or remotely; students positively evaluate lecturers who actively involve students in the study process and work together with them. Students also find it interesting and useful to listen to lecturers' stories about school, which provide an insight into a teacher's profession and daily work.

- The greatest advantage of the remote study process is wider possibilities for planning one's time, but it is also a big risk, because not all students manage to follow the developed plan and complete all the planned works. Students also lack mutual contacts with course mates and direct discussions with the lecturer when there are questions about the course content.

- Students admit when learning mathematics courses remotely, it is best to perceive the material if the lecturer works together with students, for example, writes on a graphic display or tablet, rather than just speaking or showing already prepared theoretical material. Another advantage of the remote study process is the opportunity to record lectures, which can be watched again if necessary.

- When planning the remote study process, the time spent at the computer should be considered so that it does not start to affect the student's physical health, as well as it has to be ensured that students are actively involved in the study process and do not passively watch the lecture.

\section{References}

Azhari, B., Fajri, I. (2021). Distance learning during the COVID-19 pandemic: School closure in Indonesia. International Journal of Mathematical Education in Science and Technology. https://doi.org/10.1080/0020739X.2021.1875072

Bretscher, N. (2021). Challenging assumptions about relationships between mathematics pedagogy and ICT integration: surveying teachers in English secondary schools. Research in Mathematics Education. https://doi.org/10.1080/14794802.2020.1830156

Dias-Trinidade, S., Santa, E. D. (2021). Professor's Digital Competences in Pandemic Times: Digcompedu Self-Assessment Analysis. Revista Praxis Educacional, 17(45). https:// doi.org/10.22481/praxisedu.v17i45.8336

Goksu, I., Ergun, N., Ozkan, Z., \& Sakiz, H. (2021). Distance education amid a pandemic: Which psycho-demographic variables affect students in higher education? Journal of Computer Assisted Learning. http://doi.org/10.1111/jcal.12544

Manca, S., Delfino, M. (2021). Adapting educational practices in emergency remote education: Continuity and change from a student perspective. British Journal of Educational Technology. https://doi.org/10.1111/bjet.13098 
Noteikumi par valsts vispārējās vidējās izglitïbas standartu un vispārējās vidējās izglïtibas programmu paraugiem, Latvijas Republikas Ministru kabinets, Nr. 416 (2019). [Regulations on State Secondary Education Curricula and Sample Secondary Education Programs, Cabinet of Ministers of the Republic of Latvia]. Retrieved from https://likumi.lv/ta/id/309597

Noteikumi par valsts vispārējās vidējās izglïtibas standartu, mācību priekšmetu standartiem un izglitibas programmu paraugiem, Latvijas Republikas Ministru kabinets, Nr. 281 (2013). [Regulations on State Secondary Education Curricula, Subject Standards and Samples of Educational Programs, Cabinet of Ministers of the Republic of Latvia]. Retrieved from https://likumi.lv/ta/id/257229-noteikumi-par-valsts-visparejas-videjas-izglitibas-standartu-macibu-prieksmetu-standartiem-un-izglitibas-programmu-paraugiem

National Centre for Education. (2020). Centralizēto eksāmenu vidējo rezultātu salīdzinājums 2018.-2020. [Comparison of examinations' average results 2018-2020]. Retrieved from https://www.visc.gov.lv/sites/visc/files/content/vispizglitiba/eksameni/statistika/ 2020/visi_vidrez_salidz_3g.png

National Centre for Education. (2021). Valsts pārbaudes darbu uzdevumi. [Tasks of state examinations]. Retrieved from https://www.visc.gov.lv/lv/valsts-parbaudes-darbuuzdevumi

Nobre, A., Mouraz, A., Goulao, M. D., Henriques, S., Barros, D., \& Moreira, J. A. (2021). Digital Communication Processes in the Portuguese Educational System in Pandemic Times.

Revista Praxis Educacional, 17(45). https://doi.org/10.22481/praxisedu.v17i45.8331

Paredes, S. G., Pena, F. D. J., \& Alcazar, J. M. D. (2021). Remote proctored exams: Integrity assurance in online education? Distance Education. https://doi.org./10.1080/ 01587919.2021 .1910495

Silva, J., Goulart, I. D. V., \& Cabral, G. R. (2021). Remote Teaching in Higher Education: Impacts on Initial Teacher Education. Revista Ibero-Americana de Estudos em Educacao, 16(2), 407-423. https://doi.org/10.21723/riaee.v16i2.14238

Skola 2030. (2020). Valsts izglītības satura centra îstenotais projekts "Kompetenču pieeja mācību saturā" [Project "Competency based approach in school curricula" implemented by the National Centre for Education]. Retrieved from https://skola2030.lv/lv

OECD TALIS. (2019). TALIS 2018 Results (Volume I): Teachers and School Leaders as Lifelong Learners. TALIS, OECD Publishing, Paris. https://doi.org/10.1787/1d0bc92a-en

OECD. (2019). Education at a Glance 2019: OECD Indicators. OECD Publishing, Paris. https://doi.org/10.1787/f8d7880d-en

University of Latvia. (2020). Profesionālā bakalaura studiju programma "Skolotājs". [Professional bachelor's study program "Teacher"]. Retrieved from https://www.lu.lv/ gribu-studet-ppmf/koledzas-un-bakalaura-limena-studijas/skolotajs/ 